\title{
I love you putamente
}

Lunay Estela Figueroa Arias

Estudiante de Literatura

Universidad Autónoma de Bucaramanga

lfigueroa2@unab.edu.co

Artículo recibido el 03 de octubre2014

Artículo aprobado el 27 de octubre 2014

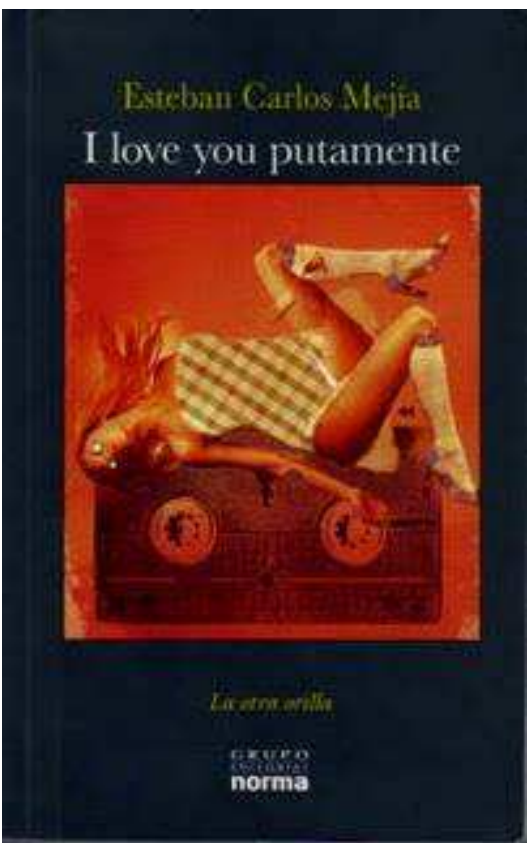

Portada del libro. Cortesía: Grupo Editorial Norma.

Título: I love you putamente

Autor: Esteban Carlos Mejía

ISBN 978-958-04-9934-3

Clasificación: Novela colombiana

Edición: $1^{\text {a }}$. Ed. $1^{\text {a }}$. Impr.

Fecha: marzo 2007

Páginas: 254 


\section{Colección: La otra Orilla - Grupo Editorial Norma}

Abordar la novela, I love you putamente (Norma, 2007) de Esteban Carlos Mejía, es dejarse sumergir temporalmente en un mar de estrategias narrativas que describen la realidad cruda y desnuda, secuela de la bonanza del narcotráfico, que permeó con furia las entrañas de la ciudad de Medellín; pero esta historia, no se limita a descarnar el alma como en la novela sicaresca, aunque la puerta de entrada a la trama se abre con un muerto, producto de un ajuste de cuentas, pronto páginas adentro, puede notarse que lo que de verdad se cuenta es algo bien diferente.

Entre saltos narrativos, juego de textos y de tiempos, el protagonista Víctor Yugo, personaje inolvidable, se encarga de narrar en primera persona, los dos tiempos que juegan en contrahilo dentro de la novela, manteniendo la tensión de la urdimbre, hasta confluir al acercarse el final de la trama y configurar el sentido total de la historia.

I love you putamente, abarca un panorama social amplio, capta circunstancias históricas concretas y reales del lado oscuro de Medellín, refleja los costos consecuentes del fenómeno del narcotráfico causales de la atmósfera de violencia, criminalidad y vicios sociales en su momento: sexo, drogas, corrupción, chantaje y demás verdades, entrelazados al extravío de los rasgos y del carácter cotidianos: la astucia, la malicia, la mentira y el aprovechamiento sin escrúpulos de la oportunidad en las mejores circunstancias. El erotismo es la hebra dorada que se hilvana, teje y desteje en la novela de Esteban Carlos Mejía, desde el deseo del amor puro y poético, pasando por la sensualidad y la pasión, hasta llegar al sexo, el engaño, la obscenidad y la perversión, en un trasegar de relaciones que se mezclan, se confunden, se filtran, se silencian y se acallan, cuando otro de los males de la tierra, aparece: la extorsión.

Se oxigena el ambiente de la novela con delicadas puntadas musicales, literarias y gastronómicas con toques de humor e ironía en las conversaciones de sus protagonistas (Víctor, Gallemo, Juliana, Luisa, Amelia, Consolata); con los accidentados recorridos en taxi por las laberínticas calles de la ciudad, donde florecen mitos urbanos que se crean y recrean en el imaginario de los taxistas y con los entretejidos recorridos de inmersión a pie o en Metro por las calles, edificios, parques, barrios y comunas que exponen a la vista del lector elementos distintivos de la ciudad, como la arquitectura, el arte, la moda y sus réplicas y la belleza de sus mujeres, definiendo y enmarcando con nitidez fotográfica el alma popular de la cultura paisa.

Aunque I love you putamente, recrea en su diseño total, una atmósfera cruda y desnuda reflejo de la verdad de una tragedia, las secuelas del narcotráfico, la criminalidad y el sicariato en Medellín, pocas veces puede leerse una novela que partiendo de esta realidad colombiana, logre con pericia narrativa describir y 
testimoniar el fenómeno, sin retraerse hacia el horror de la crónica sangrienta, del que hay suficientes testimonios e imágenes en la memoria colombiana.

La novela de Esteban Carlos Mejía, emerge con un remate sorpresivo, que abre los ojos a la verdad y resalta su capacidad para despertar conciencia en el lector sobre el impacto de un fenómeno social con trasfondo ético, político y económico, que se ovilla desde el entorno familiar y se teje en el contexto circunstancial, constituyendo un valioso aporte de acercamiento testimonial y explicativo a la historia de la vida reciente de nuestro país.

\section{El autor:}

Ex publicista de oficio, novelista de vocación. Columnista de prensa y presentador de televisión. Con el programa Especiales del Arte, del que era director y presentador, ganó en 1991 el Premio Simón Bolívar de Televisión, en Investigación Cultural. Su cuento Cuestión de escrúpulos (Gaceta, 1979) fue llevado al teatro, junto con textos de otros autores, por el Colectivo Teatral Matacandelas, entre 1982 y 1988 . Mentirás al prójimo como a ti mismo, su opera prima, ganó el Premio Nacional de Novela Editorial Universidad de Antioquia, en 2000 (primera edición, marzo de 2001). I love you putamente es la primera novela de Trilogía de espaldas a Medellín. La segunda parte de la saga, Esos besos que te doy, está lista. Hoy en día trabaja en Los abismos de tu sexo, tercera novela de la utopía. Hagan el favor de hacer silencio (Sílaba, 2013) es su última novela erótico-humorística-política. Tiene una columna en El Espectador (Rabo de Paja), un programa cultura en radio (La punta del Iceberg), y una tertulia literaria (Mesita de noche, Universidad EAFIT). 